\title{
Cohesive Devices Frequency in English Textbooks: Do They Help or Hinder EFL Reading Comprehension?
}

\author{
Natasha Pourdana (Corresponding author) \\ Department of English Translation, College of Literature and Foreign Languages, Islamic Azad University, Karaj Branch, Alborz, Iran \\ Global Education Center, Gyeongju University, South Korea \\ E-mail: natasha.qale@gmail.com \\ Mahnaz Naziri \\ mahnaznaziry@yahoo.com \\ John S. Rajeski \\ asiajsr@gmail.com
}

Received: 22-02-2014

doi:10.7575/aiac.ijalel.v.3n.4p.154
Accepted: 25-03-2014

Published: 01-07-2014

URL: http://dx.doi.org/10.7575/aiac.ijalel.v.3n.4p.154

\begin{abstract}
This study is an endeavor to demonstrate the presence of various kinds of cohesive devices through English Textbook and their possible impacts on Iranian High school students' reading comprehension. . To homogenize the subjects and divide them into two intact groups of experimental and control, Nelson Battery Test of English was administered as the pre-test. In the 12-session treatment, the experimental group read through eight selected short passages from Learning to Read English (Birjandi, AnaniSarab \& Samimi 2000) for 20 minutes per session, while the control group practiced the questions in English final exams back to previous academic years as a placebo. Both groups partook in a piloted and validated post-test. Four passages, extracted from the University Entrance Examinations in 2006, 2007, 2009 and 2011 in Iran, were read and followed by 20 multiple-choice items. The post-test was piloted and revised for an acceptable reliability estimate (Cronbach $\alpha=.761$ ). The collected data were analyzed for normality with Kolmogorov-Smirnov Test. Statistics from pre- and post-tests supported the benefits Iranian high school EFL learners would gain from a high frequency of cohesive devices in their reading texts. Moreover, the EFL learners' moderately improved proficiency level accounted for the benefits they would gain from English texts flourished with frequent cohesive devices. Findings could have some important pedagogical implications in favor of explicit teaching of cohesive devices by EFL teachers and material developers.
\end{abstract}

Keywords: Cohesive devices, Discourse, EFL, High School, Reading Comprehension

\section{Introduction}

One of the research areas in second language acquisition (SLA) that has absorbed many researchers' attention is discourse analysis, in general, and cohesion as their favorite spot. A semantic concept, cohesion refers to the sense relationship of content inside a text (Halliday \& Hasan 1976). "It paves the way for lexical and grammatical intimacy and makes sentence arrangement more a matter of comprehensible discourse than autonomous sentences".(p. 194)

According to Pearson and Johnson (1978), readers comprehend a text only when they understand cohesive devices for reformulating them in other ways. In other words, making inferences is considered as the critical act of comprehension: if they are able to crack the relationship between ideas in a text and the logical glues and ties that indicate them, they are able to figure out the conceptual and structural bridges in the text. Foss and Haykes (1978, cited in Malki 2010) claim that if reading comprehension is enhanced by syntactic, semantic and discourse clues, it will definitely lead to a more effective short-term retention and memorization.

It is hardly identical to extract the meaning of a word, to interpret a sentence, to realize intersentence connections, or to grasp the overall meaning of a text. Comprehension at discourse level is assumed to become much more efficient or deeper, if the reader activates her implicit knowledge and integrates that knowledge with the information explicitly present in the text. Undoubtedly, text comprehension by EFL learners is more successful when they generate inferences while reading the passage (Ben-Anath 2005, Crane 2000, Muto 2007, McNamara et al. 2011).

For reading comprehension is mostly effective at supra-sentential or discourse level, EFL learners should be exposed adequate and possible techniques to access discourses. This new consideration becomes the main concern of many linguists such as Michael Halliday who believes that "the historical study of linguistics first involves studying the morphology of language followed by studying the words meaning at the sentence level" (1994: 89). Ultimately, the goal of such analysis is to find the meaning in different forms and structures of a language. However, in Halliday's view, the reverse approach is more meaningful; "A language is interpreted as a system of meanings, accompanied by 
forms through which the meanings can be expressed". Beyond the grammar and vocabulary in every language, understanding the mechanisms of text structuring is the basis for most of Halliday's works.

The seven criteria in a written or a spoken text for being called a discourse, have been suggested by Beaugrande and Dressler (1981, cited in Alba-Juez 2009). They include: (1) Cohesion; it has to do with the relationship between text and syntax. Phenomena such as conjunction, ellipsis, anaphora, cataphora or recurrence are basic in cohesion. (2) Coherence; it refers to implicit the meaning of the text. Here we focus on those elements of knowledge or cognitive structures that for them we have no linguistic realizations but they are implied by every language user, and thus will influence their reception of the message. (3) Intentionality, which relates to the attitude and purpose of the speaker or writer. (4) Acceptability; it is concerned with preparing the hearer or reader to assess the relevance or usefulness of a given text. (5) Informativity, which refers to the quantity and/or quality of new or expected information. (6) Situationality; it points to the fact that the context wherein the text is produced has a crucial role in production and reception of the textual message. Finally, (7) Intertextuality; it refers to two main facts of whether a text is directly related to some preceding or simultaneous discourse, or whether a text is properly linked or grouped to particular text varieties or genres (e.g., narrative, argumentative, descriptive, etc.) by some predetermined formal criteria.

Tischer et al. (2000, cited in Olateju 2006) explain that cohesion and coherence can be considered as intra-textual criteria, whereas the remaining criteria are mostly inter-textual. The oriented approaches towards 'pure' text linguistics put more emphasis on the text-internal criteria, while the traditional approaches in discourse analysis have always given more importance to the external factors as essential components of communication. In other terms, while the text-internal elements constitute the text, the text-external elements comprise the context.

Cohesion is described in a number of ways. McCarthy (1991:78) defines it from a grammatical point of view "as any surface marking of semantic links between clauses and sentences in a written discourse". He emphasizes "it is due to the grammar of English to offer a limited set of choices to create this link". Moreover, such link is achieved only by cohesion which is displayed from sentence to sentence "by means of grammatical features such as pronominalisation, ellipsis, and conjunction" (1991: 210). A process rather than a product, according to Widdowson (2006), cohesion is the process of pinpointing and identifying the connections which are linguistically signaled, for example, between a pronoun and a noun phrase.

Accordingly, to Halliday and Hasan (1976), cohesion exists where the interpretation of some element in the discourse is confined to, or "presupposes", some other elements in the sense that one cannot be effectively broken down except by recourse to the other. When this process starts, cohesion is set up, and those two elements - the presupposing and the presupposed - are thereby glued into a text.

For several years, the analysis of cohesion in English texts has been a key topic in the study of discourse. Following Halliday's Systemic Grammar, Bell (1991) mentions the three macro functions of language: ideational (related to meaning), interpersonal (related to the reader/hearer) and textual (related to text organization). Bell places cohesion within the textual function, since it contributes to organize the propositional content (ideational function) and brings the utterances together to "constitute a linguistically linked text".

A detailed classified list of cohesive devices is presented by Halliday and Hasan (1976). They identify five major types of cohesion in English: (1) References (pronominals, demonstratives, definite articles and comparatives), (2) Conjunctions (additives, adversatives, causals, temporals, and continuatives), (3) Lexical reiterations and collocations which are known as Lexical cohesion, (synonymous, superordinates, and general items), (4) Substitutions, and (5) Ellipsis.

Many researchers hypothesize that textual cohesive conjunctions may facilitate reading comprehension in both L1 and L2 texts (Innajih 2007, Rahemi 2009, Silveria 2008, Eggins 1994). McNamara, Best, and Castellano (2003, cited in Malki 2010) argue that the function of cohesive ties is to pave the way for the readers to easily and efficiently understand the connection between ideas within the text. Therefore, many EFL educators have investigated the role of cohesion in more reflective language teaching pedagogy (e.g., Kai 2008, Xi 2010). Some studies support the significant roles that the lexical cohesive devices play in comprehension of a text (Morris 2006, Maleki 2010). Nunan (1993, cited in Yeh, Yang \& Wong 2010), however, puts more stress upon the EFL learners' ability to identify the cohesive devices across sentence boundaries as a determining intra-textual factor. Recent studies on controlling strategies in reading process support the fact that EFL readers' comprehension are effectively improved by explicit textual connectors. (Lightman, McCarthy \& McNamara 2007).

Two noticeably different approaches to text processing lead to the distinction between the manners EFL learners attend to written communicative products. Bottom-up processing involves assimilating the reading input from the smallest chunks of discourse, such as individual sounds in speech or letters in texts, moving afterwards to more and more general features. This technique is frequently applied by the language learners at elementary levels who pay much attention to decoding particular words that they often lose the global meaning encoded in the text. While it is considered to be a good way of making learners understand the language bits and particles, a wider perspective is necessary to enable the learners to successfully work with comprehensible discourse (Cook 1990).

Alternatively, top-down processing starts with general features encoded in a text and gradually moves to the narrower aspects of language. This holistic approach considers all levels of communicative products as a total unit wherein the elements work collectively. Not only does the information in a text enable the readers to understand it, but also it has 
to be attacked with the recipient's former knowledge of the world and language as well as exploring expectations that facilitate comprehension.

It is important to make language learners aware of these two ways of dealing with discourse and how they may be effectively exploited for better comprehension. When EFL learners are introduced to the main idea presented by a particular communicative product, they should take advantage of top-down processing, while when they are expected to reply to some detailed true-false questions they would benefit from bottom-up processing (Cook 1990, McCarthy 1991).

In line with the previous works in EFL teaching skills, the purpose for conducting this research was to investigate the positive role of cohesive devices in the texts to improve the reading comprehension by EFL learners at different proficiency levels. The researchers' assumption was that higher frequency of cohesive devices in English textbooks would affect the reading comprehension by both higher and lower level EFL learners.

\section{Method}

Sixty-four participants in this study were selected among the population of senior students in Farzaneh High school, Kerman, Iran (N=97). The subjects were all Iranian, female and between 17 to 18 years of age. They were selected with a convenience sampling method. In order to homogenize the subjects, Nelson Battery Test of English was administered as the pre-test. The test is originally comprised of a cloze test followed by 14 multiple-choice items and 36 items on English vocabulary and grammar. Four students whose scores were two standard deviations beyond the mean score in Nelson Battery Test were excluded from the sample $(X=15,17,37,40)$. The remained subjects were divided into two intact groups of control and experimental $(\mathrm{N}=32)$.

The experimental group received eight passages of approximately 500-700 words extracted from the Learning to Read English (Birjandi, AnaniSarab \& Samimi 2007) as the 20-minute treatment in this experiment. The treatment lasted for 12 sessions. Cohesive devices were taught within the context of sentences. Every cohesive device was bolded and italicized in every passage (Appendix A). The students' reading comprehension was checked through follow-up questions. The control group practiced the questions administered in English final exams back to previous years as a placebo during the 12 sessions of the experiment.

The passages selected in the post-test were adopted from the University Entrance Examination in 2006, 2007, 2009 and 2011 in Iran. The post-test consisted of four reading passages each followed by five multiple-choice items $(\mathrm{k}=20)$. The test was piloted with 20 high school students similar to the sample group in proficiency level, age and gender. Every item was analyzed for its item facility and item discrimination in further revisions. The final draft was validated with 10 more students (Cronbach $\alpha=.761$ ). Finally, the post-test was administrated with both the experimental group and control group (Appendix B).

\section{Results and Discussion}

The scores on Nelson Battery of English Test were descriptively analyzed (Table 1). To homogenize the sample, the scores beyond 2 Standard Deviations from the mean score in Nelson Battery of English Test were excluded from the sample $(\mathrm{X}=15,17,37,40)$.

Table 1. Nelson Battery of English Test

\begin{tabular}{rrrrrr}
\hline $\mathrm{N}$ & Min & Max & Mean & Std. Deviation & Variance \\
\hline 68 & 15.00 & 40.00 & 24.72 & 4.31 & 18.6 \\
\hline
\end{tabular}

After excluding the 4 outlier scores and presenting the treatment and placebo, the subjects participated in a 30 minute post-test.

Table 2. Post-Test Scores

\begin{tabular}{rrrrrr}
\hline Group & $\mathrm{N}$ & Mean & $\begin{array}{r}\text { Std. } \\
\text { Deviation }\end{array}$ & $\begin{array}{r}\text { Std. Error } \\
\text { Mean }\end{array}$ \\
\hline $\begin{array}{r}\text { Control Group } \\
32\end{array}$ & 14.33 & 2.56 & .44 & \\
\hline $\begin{array}{r}\text { Experimental } \\
\text { Group }\end{array}$ & 32 & 17.71 & 3.52 & .62 & \\
\hline
\end{tabular}

To determine the effect size of the treatment (Rosental 1994, Larson-Hall 2011), the Cohen's d which measures the differences between two independent sample means was calculated. Cohen's $d=.96$ showed a satisfactorily large effect size. The normality of both group scores on pre and post-tests - for further decisions on the type of parametric and non-parametric data analysis procedures - was investigated with the Kolmogorov-Smirnov test in SPSS 19. The assumption of Equality of Variances in Levene's Test was not rejected; therefore, two parametric tests of Pearson Product-moment correlation and Independent Samples T-test were conducted. 
In order to detect the differences between the performance of the experimental group and control group on post-test, an Independent Samples T-Test was conducted.

Table 3. Independent Samples T-Test

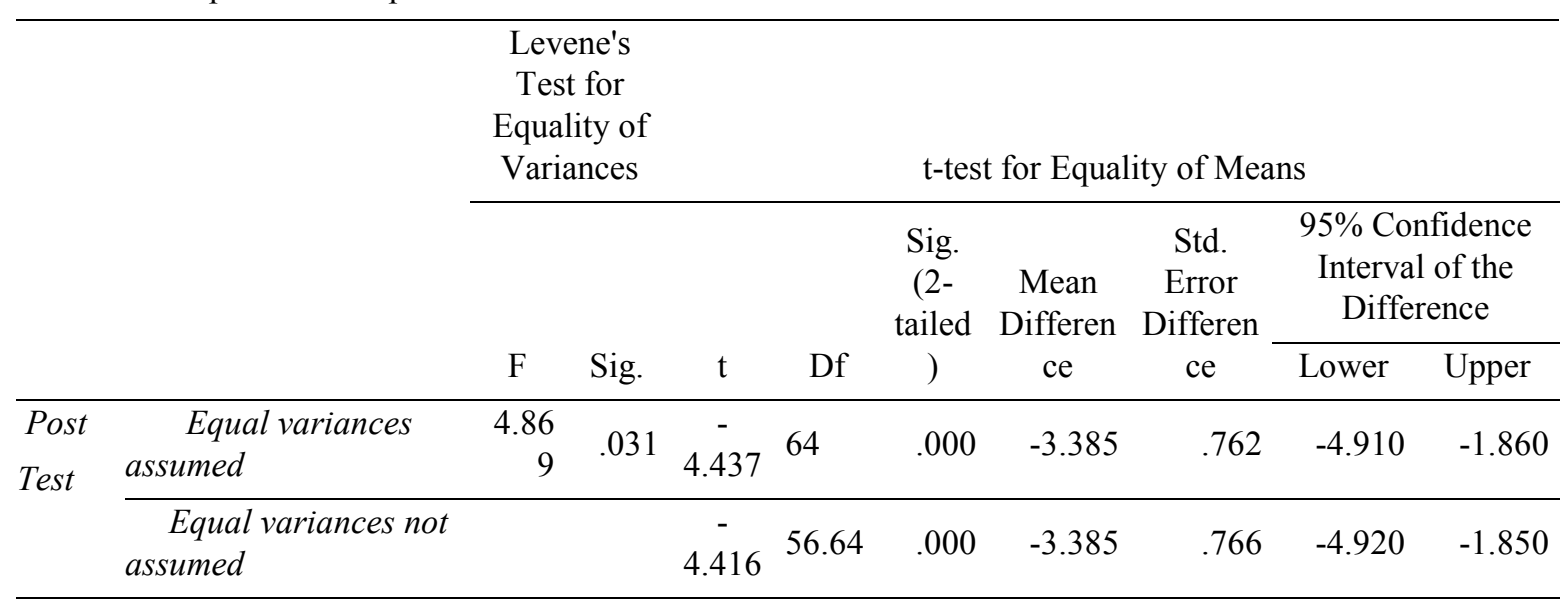

As Table 3 shows, the amount of $\mathrm{t}(-4.437, \mathrm{df}=64)$, significant at $\mathrm{p}$-value $<0.05$, proved that the experimental group outperformed the control group on post-test after receiving instructions on cohesive devices. In order to investigate the possible relationship between the EFL learners' level of proficiency and their advantage from cohesive devices, Pearson product-moment correlation was conducted with the scores on pre- and post-test for the experimental group.

Table 4. Correlation Between Experimental Group's Performance on Pre- and Post-Tests

\begin{tabular}{cccc}
\hline & & Pretest & Posttest \\
\hline Pretest & Pearson Correlation & 1 & $.399^{*}$ \\
\cline { 2 - 4 } & Sig. (2-tailed) & & .024 \\
\cline { 2 - 4 } & $\mathrm{N}$ & 32 & 32 \\
\hline Posttest & Pearson Correlation & $.399^{*}$ & 1 \\
\cline { 2 - 4 } & Sig. (2-tailed) & .024 & 32 \\
\cline { 2 - 4 } & $\mathrm{N}$ & 32 & 32 \\
\hline
\end{tabular}

As Table 4 shows, the Pearson correlation test statistics $(\mathrm{r}=0.399)$ is significant at the $\mathrm{p}$-value $<0.01$ which proves a moderate relationship between the proficiency level of the EFL learners and the benefits they gain from English texts with frequent appearance of cohesive devices.

The initial assumption of the researchers on the benefits both higher achievers and lower achievers take from presenting cohesive devices is not fully supported by the moderate, if not low, correlation between the pre-test and post-test performance of the experimental group ( $r=.399$ significant at $p$-value $<0.05)$. This finding may imply a careful presentation of cohesive devices to the EFL lower achievers who have a more limited grammatical and structural competence than the higher achievers and are probably less apt to focus on language forms.

\section{Conclusion}

Some of the problems originated in reading comprehension of English texts are related to little attention the material developers and school teachers have paid to the proper distribution of cohesive devices in the texts book and teachermade texts. Successful comprehension of English texts at different levels of difficulty and of various genres is one of the greatest challenges for language learners in most non-English speaking countries such as Iran. High school and university students are assigned to reading various English texts and articles related to their fields of study. Yet, what is common among these EFL learners is the lack of effective reading skills to improve their speed and comprehension of the texts in and out of the classroom. Poor reading comprehension skills may cause serious problems for EFL learners since it is one of the determining factors in their future success. This problem is doubled in countries English is learned by a large number of students who rarely have the opportunity of conversing with native speakers or they randomly have access to the scientific or technical journals written in English (Rivers 1986).

Findings in this study reassure the relative usefulness of cohesive devices for EFL learners in their reading comprehension. The explicit teaching of cohesive devices is proved to have a significant impact on improving the reading comprehension skills in EFL classrooms. The statistically supported fact that both lower-level and higherlevel EFL learners would benefit, if not equally, from frequency of cohesive devices in reading texts is promising to both EFL teachers and ELT material developers. Teaching how to read English passages beyond the sentential level gives a way to a more discourse oriented approach to EFL text comprehension. 


\section{References}

Alba-Juez, L. (2009). Perspectives on discourse analysis: theory and practice. Cambridge: Cambridge scholar publishing. Retrieved November 27, 2011, from http://www.c-s-p.org/flyers/978-1-4438-0597-1-sample.pdf

Bell, R. (1991). Translation and translating: theory and practice. London and New York: Longman.

Ben-Anath, D. (2005). The role of connectives in text comprehension. TESOL and Applied Linguistics, 5(2), 1-27. Retrieved April 12, 2012 from http://journals.tc-library.org/index.php/tesol/article/view/84/87

Birjandi, P., AnaniSarab, M. R. \& Samimi, D. (2007). Learning to Read English. Tehran: Iran Textbooks Publisher. Cook, G. (1990). Discourse. Oxford: Oxford University Press.

Crane, P. A. (2000). Texture in text: A discourse analysis of a news article using Halliday and Hasan's model of Cohesion. Retrieved November 23, 2011, from http://library.nakanishi.ac.jp/kiyou/gaidai(30)/08.pdf

Eggins, S. (1994). An Introduction to Systemic Functional Linguistics. London: Pinter.

Halliday, M. A. K., \& Hasan, R. (1976). Cohesion in English. London: Longman.

Innajih, A. A. (2007). The impact of textual cohesive conjunctions on the reading comprehension of foreign language students. ARECLS E-Journal, 3, 1-20. Retrieved November 23, 2011, from http://research.ncl.ac.uk/ARECLS/volume_4/INNAJIH.pdf

Kai, J. (2008). Lexical cohesion patterns in NS and NNS dissertation abstracts in applied linguistics: A comparative study. Linguistics Journal, 3, 132-144. Retrieved November 30, 2011, fromhttp://www.linguisticsjournal.com/December_2008.pdf

Larson-Hall, J. (2011). A guide to doing statistics in second language research using SPSS. London: Routledge.

Laybutt, B. E. (2009). A comparative corpus study between a genre of written sport reports and a large reference corpus. Unpublished doctoral dissertation, University of Birmingham- England. Retrieved December 10, 2011, fromhttp://www.birmingham.ac.uk/Documents/college artslaw/cels/essays/matefltesldissertations/Thesis-Laybutt.pdf

Malki, F. (2010). The Role of cohesive markers in reading scientific texts. Unpublished doctoral dissertation. University of Mentouri-Constantine.Retrieved December 15, 2011, from http://bu.umc.edu.dz/theses/anglais/MAL1105.\%20.pdf

McCarthy, M. (1991). Discourse analysis for language teachers. Cambridge: Cambridge University Press.

McNamara, D. S., Ozuru, Y., \& Floyd, R. G. (2011) .Comprehension challenges in the fourth grade: The roles of text cohesion, text genre, and reader's prior knowledge. International Electronic Journal of Elementary Education (IEJEE), 4(1), 229-257. Retrieved October 23, 2011, from

http://www.iejee.com/4_1_2011/13_IEJEE_4_1_McNamara_Ozuru_Floyd.pdf

Morris, J. (2006). Readers' subjective perceptions of lexical cohesion and implications for computers' interpretations of text meaning. CaSTA Symposium on text analysis. Canada, 12 October 2006. Retrieved December 15, 2011, from http://dspace.hil.unb.ca:8080/bitstream/handle/1882/975/morris.pdf?sequence...

Muto, K. (2007). The Use of Lexical Cohesion in Reading and Writing. Retrieved January 10, 2011 from http://library.nakanishi.ac.jp/kiyou/gaidai(30)/07.pdf.

Olateju, M. (2006). Cohesion in ESL classroom written texts. Nordic Journal of African Studies, 15(3), PP.314-331. Retrieved November 30, 2011, from http://www.njas.helsinki.fi/pdf-files/vol15num3/olateju.pdf

Perason, P. D., \& Johnson, D. D. (1978). Teaching reading comprehension. New York: Holt, Rinehart \&Winston.

Rahemi, J. (2009). Reciprocal teaching as a tool to foster autonomy: Practical considerations in Iranian high school. Roshd FLT 89(23), pp. 29-36.

Rivers,W.M. (1981). Teaching foreign language skills. Chicago: university of Chicago press.

Rosenthal, R. (1994). Parametric measures of effect size. In H. Cooper \& L. V. Hedges (Eds.), The Handbook of Research Synthesis (pp. 231-244). New York: Russell Sage Foundation.

Silveira, R. (2008). Cohesive devices and translation: An analysis. Retrieved January 12, 2011 from http://www.periodicos.ufsc.br/index.php/traducao/article/download/5241/4628.

Widdowson, H. G. (2006). Discourse Analysis. Oxford: Oxford University Press.

$\mathrm{Xi}, \mathrm{Y}$. (2010).Cohesion studies in the past 30 years: Development, application and chaos. University of MaCau, The International Journal Language Society and Culture, ISSN 1327- 774X, 31. Retrieved October 21, 2011 from http://www.educ.utas.edu.au/users/tle/JOURNAL/issues/2010/31-17.pdf

Yeh, H. C., Yong, Y. F., \& Wong, W. K. (2010). Interaction chain patterns of on line text construction with lexical cohesion. Educational Technology and Science Journal, 13(1), pp.55- 68. Retrieved April 12, 2012, from http://www.ifets.info/journals/13_1/7.pdf 
Appendix A

Frequency of Cohesive Devices

\begin{tabular}{|c|c|c|c|c|c|c|c|c|c|}
\hline Cohesive Devices & $\begin{array}{r}\text { Passage } \\
\text { one }\end{array}$ & $\begin{array}{r}\text { Passage } \\
\text { two }\end{array}$ & $\begin{array}{r}\text { Passage } \\
\text { three }\end{array}$ & $\begin{array}{r}\text { Passage } \\
\text { four }\end{array}$ & $\begin{array}{r}\text { Passage } \\
\text { five }\end{array}$ & $\begin{array}{r}\text { Passage } \\
\text { six }\end{array}$ & $\begin{array}{r}\text { Passage } \\
\text { seven }\end{array}$ & $\begin{array}{r}\text { Passage } \\
\text { eight }\end{array}$ & Total \\
\hline Substitution & 1 & 2 & 1 & - & 1 & - & 2 & 1 & 8 \\
\hline Ellipsis & 1 & 4 & 5 & - & 2 & 6 & 6 & 5 & 29 \\
\hline Conjunction & 19 & 13 & 12 & 17 & 17 & 13 & 17 & 11 & 119 \\
\hline Same item & 24 & 39 & 33 & 23 & 20 & 26 & 23 & 18 & 206 \\
\hline Synonym & 2 & 5 & 7 & 3 & 2 & 2 & 5 & 1 & 27 \\
\hline Collocation & 16 & 4 & 20 & 13 & 18 & 15 & 13 & 9 & 108 \\
\hline
\end{tabular}

\section{Appendix B}

\section{Post-Test (Final Version)}

Read the following passages carefully and answer the questions by choosing the best choices a, b, $c$, or $d$. Then mark your answer sheet.

Most scientists think that by resting our bodies, we allow time for essential maintenance work to be done. Any damage that there is can be put right more quickly if energy isn't being used up doing other things. Injured animals certainly spend more time asleep than usual while their wounds are healing. And quite a few illnesses make us feel sleepy, so our body can get on with curing us.

Sleep is controlled by certain chemicals. These are built up during the day, eventually reaching levels that make us tired. We can control the effects of these chemicals to some extent. Caffeine helps keep us awake while some medicines make us sleepy.

By using electrodes, scientists are able to study what goes on in people's heads while they sleep. They have discovered that when we first drop off everything slows down. The heart beats more slowly and our breathing becomes shallow. After about 90 minutes our eyes start to twitch and we go into what is called REM sleep. REM stands for Rapid Eye Movement, and it's a sign that we've started to dream.

1. The best title for the passage is:
a) Why we dream
b) Facts about Sleep
c) Effect of chemicals on sleep
d) Effects of Sleep on Health

2. Human sleep is the result of .
a) some chemicals
b) the need to store energy
c) some diseases
d) the slowing down of our heartbeat

3. The word "they " in paragraph 3 line 2 refers to
a) heads
b) electrodes
c) scientists
d) people

4. The word "twitch" in paragraph 3 line 4 is closest is meaning to
a) drop
b) close
c) move
d) become heavy

5. According to the passage, all of the following happen during asleep EXCEPT
a) shallow breath
b) less heart activity
c) Rapid Eye Movement
d) increased need for caffeine 
When people today speak of cartoons, they usually mean the comic drawings which appear in almost every newspaper and magazine, drawings of some scene or situation intended to be funny. Some newspaper cartoons, of course, especially the ones about politics, are critical; they explain a significant or interesting event of the moment in a way that shows up its importance. They often contain caricatures enlarged and comic portraits of real people( politicians for instance) - for if a cartoonist wants to criticize a political leader or show that he dislikes him, one of the best ways is to make him look silly and funny in a cartoon.

Another use of the word cartoon means the kind of "strip cartoon" in newspapers and comics which tells a story in a set of little pictures. Some strip cartoons do not have words; others include conversations in the drawing in areas called "balloons".

Cartoon films, such as those of Walt Disney, are 'animated cartoons"; that is, they are films made from a great number of separate drawings photographed one after another and shown very quickly on the screen so that the figures on them seem to move.

6. Which kind of cartoons has a more serious purpose?
a) Portraits
b) Strip cartoons
c) Political cartoons
d) Cartoon films

7. In the phrase "strip cartoons", "strip" means
a) a balloon
b) without words
c) a drawing
d) a narrow piece

8. Which sentence about the passage is NOT true?

a) Comic drawings of some scenes or situations make us laugh.

b) Some people believe that cartoons are anything which makes us laugh.

c) Some cartoons explain a significant or interesting event.

d) Most cartoons which appear in magazines or newspapers make us laugh.

9. The cartoon films made by Walt Disney are
a) cartoon strips
b) based on one drawing
c) included in balloons
d) a number of moving figures

10. The best title for the passage can be
a) "Making Cartoons"
b) "Newspaper Cartoons"
c) "Kinds of Cartoons"
d) "Magazine Cartoons"

Before Newton's time, scientists knew about gravity. They knew that gravity makes objects fall to the ground and keeps houses and people from being thrown into space. Could it be, Newton asked himself, that the earth pulls the moon and keeps it from running away? And could it be that the sun pulls the earth and the other planets and helps keep them in their paths? Newton thought so.

At first he could not prove that his idea was right. He himself decided that he was on the wrong track. But years later he worked again on the problem and found out that he had been right after all. He wrote a famous book about gravity.

Newton made many other discoveries. Some of them were about light. He found out, for instance, that sunlight is made up of the rainbow colors. He studied sunlight partly by blowing soap bubbles and watching the colors in them. His neighbors were surprised to see a grown man blowing bubbles for hours at a time.

Newton wanted to find out more about the planets and the other heavenly bodies. But he was not satisfied with the telescopes that were available. To get a better one he invented a new kind, reflecting telescope. It helped him find out many new things about the sky.

\section{Scientists who lived before Newton}

a) were familiar with what we now call gravity

b) did not know why objects fell to the ground

c) did not understand that some forces help them tied to the Earth

d) were amazed at the fact that houses kept sticking to the ground 
12. Newton wrote his first book when he

a) realized that his ideas were correct

b) found out he was on the wrong track

c) decided to become famous in his country

d) decided to share his experiments with other scientists

13. The phrase "made up" in paragraph 3 is closest in meaning to
a) bent
b) built
c) consisted of
d) separated

14. The word "one" in paragraph 4 refers to
a) kind
b) view
c) experiment
d) telescope

15. The word "it" in paragraph 4 refers to
a) invention
b sky
c) reflecting telescope
d) thing

The calendar is a method by which people measure time for their own civil or religious purposes, dividing it into years, months, weeks and days. People of ancient times based the earliest calendars on the most obvious regular events they knew - the movements of the Sun and Moon, which together produce the three simplest divisions of time. These are the day, the lunar month, and the solar year.

We now know that the regular movement of the Sun across the sky is the time taken by the Earth to revolve on its axis - just under 24 hours. The lunar month is the time between two new moons - about 29.5 days. ("Lunar" comes from luna, the Latin word for "moon"). The solar year is the time taken by the Earth to travel round the Sun -365 days 5 hours 48 minutes 46 seconds.("Solar" comes from sol, the Latin word for "sun".)

Because these lengths of time do not add up to round numbers, and because the lunar months do not fit into the solar year, it was many centuries before a calendar was developed that did not have to be corrected every now and then. The importance of finding such a calendar had been known for thousands of year.

16. The passage is concerned with
a) a way to measure time
b) the difference between two calendars
c) showing the importance of time in man's life
d) describing the movements of space objects

17. According to the passage, the movements of the Sun and Moon
a) happen on a regular basis
b) were unknown to ancient people
c) include three different parts
d) were described in the earliest calendars

18. The word "its" in line 7 refers to
a) sky
b) Sun
c) Earth
d) movement

19. How many Latin words are mentioned in the passage?
a) 1
b) 2
c) 3
d) 4

20. It can be understood from the passage that

a) Greeks were the first people o invent calendar

b) the earliest calendars had to be fixed from time to time

c) the absence of an exact calendar led to problems in early peoples' life

d) it was not a long time ago before man realized he needed to develop a correct calendar 